\title{
KOMPENSASI SERTA MOTIVASI KERJA PADA KINERJA KEPERAWATAN KONTRAK RUMAH SAKIT UMUM SUBANG
}

\author{
Tiffany Juliandiny \\ Universitas Pendidikan Indonesia \\ tiffany.juliandiny@student.upi.edu \\ Syamsul Hadi Senen \\ UniversitasPendidikan Indonesia \\ syamsulhadisenen@upi.edu \\ Sumiyati \\ Universitas Pendidikan Indonesia \\ sumiyati@upi.edu
}

\begin{abstract}
ABSTRAK
Tujuan - Penelitian ini rendahnya kinerja perawat kontrak, hal tersebut ditandai dengan turunnya hasil penilaian kinerja perawat kontrak, serta seringnya ketidak hadiran menyebabkan kinerja perawat menurun.

Desain/metodologi/pendektan - Penelitian ini dilakukan pada kurung waktu kurang dari satu tahun maka metode penelitian yang digunakan adalah cross sectional method, dan di sebarkan pada 112 responden perawat kontrak rumah sakit umum Subang.

Temuan - Berdasarkan hasil penelitian secara empirik diperoleh keterangan bahwa pelaksanaan kompensasi dan motivasi yang diterapkan di Rumah Sakit Umum Subang mempunyai pengaruh secara keseluruhan sebesar 54\% terhadap kinerja, sedangkan $45 \%$ dipengaruhi faktor lainnya.

Orisinalitas - Terdapat persamaan dan perbedaan hasil penelitian yang diteliti penulis dengan peneliti sebelumnya. Persamaannya adalah dalam penelitian ini penulis menggunakan variabel yang sama, baik kompensasi, motivasi kerja maupun kinerja karyawan.
\end{abstract}

Kata kunci: Kompensasi, Motivasi, Kinerja Karyawan

Paper type Penulisan Karya Ilmiah

Pembangunan kesehatan adalah upaya yang dilaksanakan oleh semua komponen Bangsa Indonesia yang bertujuan untuk meningkatkan kesadaran, kemauan, dan kemampuan hidup sehat bagi setiap orang agar terwujud derajat kesehatan masyarakat yang setinggi-tingginya, sebagai investasi bagi pembangunan sumber daya manusia yang produktif secara sosial dan ekonomis. Pembangunan Nasional harus berwawasan kesehatan, yaitu setiap kebijakan publik selalu memperhatikan dampak pada kesehatan (Kementrian Kesehatan,2014)

Salah satu langkah pembangunan kesehatan di Indonesia adalah dengan adanya rumah sakit. Rumah sakit adalah salah satu sektor publik yang bergerak dalam bidang pelayanan jasa kesehatan yang mempunyai tugas melakukan suatu upaya kesehatan secara berdaya guna dan berhasil guna dengan mengutamakan atau meningkatkan upaya penyembuhan dan pemulihan yang telah direncanakan secara serasi dan terpadu oleh pihak rumah sakit.

Rumah Sakit Umum Daerah Subang sebagai rujukan pelayanan kesehatan yang memberikan pelayanan yang optimal dan meningkatkan mutu terus menerus. Oleh karena itu Rumah Sakit Umum Daerah Subang harus meningkatkan mutu kinerja agar dapat menambah kepercayaan masyarakat atas pelayanan di Rumah Sakit Umum Subang. Tercapainya suatu pelayanan rumah sakit yang baik salah satunya terletak pada kinerja tenaga kesehatan pada rumah sakit tersebut yaitu sebagai sumber daya manusia (SDM). Dalam menjalankan pelayanan kesehatan di rumah sakit tenaga kesehatan merupakan sumber daya yang penting dan sangat dibutuhkan untuk mencapai kinerja yang optimal.

\section{PENDAHULUAN}

Pencapaian tujuan Rumah Sakit diperoleh dari upaya yang dilakukan oleh pihak Rumah Sakit dalam mengelola dan mengatur sumber daya manusia yang memiliki potensi baik agar terus meningkatkan hasil kerjanya, ditambah dengan meningkatnya BOR pelayanan rawat inap Rumah Sakit. Perhitungan BOR (Bed Occupancy Rate) merupakan salah satu indikator yang menggambarkan tinggi rendahnya tingkat 
pemanfaatan tempat tidur rumah sakit yakni persentase pemakaian tempat tidur pada satu satuan tertentu, rendahnya tingkat BOR yang dicapai. Rendahnya tingkat BOR (Bed Occupancy Rate) yang dicapai sebenarnya menggambarkan bahwa kualitas pelayanan dari rumah sakit yang bersangkutan rendah. Salah satu alasan yang menyebabkan rendahnya nilai BOR ini adalah rendahnya kualitas pelayanan di rumah sakit tersebut, maka karyawan harus lebih cekatan dan tepat waktu dalam kerjanya. Jika angka BOR rendah maka pihak manajemen rumah sakit yang bersangkutan seharusnya meningkatkan kualitas pelayanannya pada pasien, terutama bagi mereka yang sedang dalam rawat inap. Salah satu hal yang mempengaruhi buruknya pelayanan di rumah sakit dilihat dari kinerja perawat yang menurun, pada perawat ditandai pula dengan rendahnya tingkat presensi karyawan saat hadir di tempat kerja sebenarnya menggambarkan bahwa kualitas pelayanan dari rumah sakit yang bersangkutan rendah.

\section{KAJIAN PUSTAKA}

Pendekatan yang digunakan dalam memecahkan masalah penelitian ini yaitu konsep kompensasi. Sastrohadiwiryo dalam buku (Yuniarsih, 2009) mengemukakan bahwa "kompensasi adalah imbalan balas jasa yang diberikan oleh perusahaan kepada para tenaga kerja, karena tenaga kerja tersebut telah memberikan sumbangan tenaga dan pikiran demi kemajuan perusahaan guna mencapai tujuan yang ditetapkan." William B. Verther dan Keith Davis dalam buku Malayu S.P Hasibuan (Hasibuan, Malayu, 2003) berpendapat bahwa "Compensation is what employee in exchange of their work/es or periodic salaries, the personnel department usuallys designs and administers employee compensation." Artinya: kompensasi adalah apa yang seorang pekerja terima sebagai balasan pekerjaan yang diberikannya. Baik upah per jam ataupun gaji periodik didesain dan dikelola oleh bagian personalia,menurut (Effendi Marihot Tua, 2010) mengemukakan bahwa kompensasi adalah keseluruhan balas jasa yang diterima oleh pegawai sebagai akibat dari pelaksanaan pekerjaan di organisasi dalam bentuk uang atau lainnya, yang dapat berupa gaji upah, bonus, insentif, dan tunjangan hari raya, uang makan, uang cuti, dan lain-lain. Pengertian yang lebih sederhana diajukan oleh (Rivai, Veithzal dan Sagala, 2010) Kompensasi merupakan sesuatu yang diterima pegawai sebagai pengganti kontribusi jasa mereka pada perusahaan. Pengertian yang diajukan oleh Veithzal Rifai dan Sagala tersebut menekankan bahwa kompensasi hanya berlaku dalam suatu hubungan kerja antara individu dengan perusahaan. Kompensasi menurut (Pamela F, 2012) "Total of all rewards provided to employees in return for their services." Jumlah seluruh penghargaan yang dibayarkan untuk karyawan hasil dari pekerjaannya.

Gary Dessler (Dessler, 2011) "Compensation of employees is any form of payment or reward given to employees and arising from their employment." Artinya: kompensasi adalah sebagian dari bentuk pembayaran atau penghargaan yang diberikan kepada karyawan atas jabatan mereka. menurut Gary Dessler dalam buku (Yuniarsih, 2009) yaitu pembayaran upah secara langsung (direct financial payment), pembayaran tidak langsung (indirect payment), Ganjaran nonfinansial (nonfinancial rewards). Kemudian dimensi kompensasi menurut Veithzal Rifai (Rivai, Veithzal dan Sagala, 2010) yaitu :

1. Gaji adalah balas jasa dalam bentuk uang yang diterima karyawan sebagai konsekuensi dari kedudukannya sebagai seorang karyawan yang memberikan sumbangan tenaga dan pikiran dalam mencapai tujuan perusahaan.Atau, dapat juga dikatakan sebagai bayaran tetap yang diterima seseorang dari keanggotaannya dalam sebuah perusahaan.

2. Upah merupakan imbalan finansial langsung yang dibayarkan kepada karyawan berdasarkan jam kerja, jumlah barang yang dihasilkan atau banyaknya pelayanan yang diberikan. Jadi tidak seperti gaji yang jumlahnya relatif tetap, besarnya upah dapat berubah-ubah tergantung pada keluaran yang dihasilkan.

3. Insentif merupakan imbalan langsung yang dibayarkan kepada karyawan karena kinerjanya melebihi standar yang ditentukan. Insentif merupakan bentuk lain dari upah langsung di luar upah dan gaji yang merupakan kompensasi tetap, yang biasa disebut kompensasi berdasarkan kinerja (pay for performance plan).

4. Kompensasi Tidak Langsung (Fringe Benefit). Fringe Benefit merupakan kompensasi tambahan yang diberikan berdasarkan kebijakan perusahaan terhadap semua karyawan sebagai upaya meningkatkan kesejahteraan para karyawan. Contohnya, berupa fasilitas-fasilitas, seperti: asuransi-asuransi, tunjangan-tunjangan, uang dan lain-lain.

Motivasi mempersoalkan bagaimana caranya mengarahkan daya potensi bawahan agar mau bekerja secara produktif berhasil mencapai dan mewujudkan tujuan yang telah ditentukan. Motivasi kerja terdiri dari dua kata yaitu motivasi dan kerja. Dalam melakukan pengembangan 
SDM ada beberapa pendekatan diantaranya melalui pendekatan motivasi, karena seorang individu, pegawai juga mempunyai sesuatu yang utama mengenai perilaku, sikap, tabiat dan kebiasaan-kebiasaan yang tumbuh dan berkembang yang dibentuk oleh kondisi lingkungan dan pengalaman-pengalaman di tempat kerjanya. Tujuan organisasi akan sulit dicapai, bila para pegawai tidak mau menggali potensi yang ada dalam dirinya untuk bekerja semaksimal mungkin. Dengan kata lain pemberian motivasi oleh organisasi adalah agar pegawai tetap bekerja dengan baik dan selalu memberikan prestasi yang terbaik bagi organisasi. Menjadi kewajiban dari setiap pemimpin untuk mendorong dan memotivasi setiap bawahannya untuk berprestasi.

Motivasi mempunyai peranan penting dalam pencapaian tujuan perusahaan, dapat dikatakan kemajuan suatu organisasi berawal dari motivasi yang dimiliki oleh para karyawannya. Banyak perusahaan yang selalu me-refresh motivasi dalam bekerja agar selalu dapat membawa kemajuan, meskipun untuk itu perusahaan terkadang harus mengeluarkan biaya yang tidak sedikit demi pencapaian tujuan perusahaan lewat motivasi itu sendiri (Alma, 2004). Pencapaian tujuan suatu organisasi sangat bergantung kepada kemauan para pegawai untuk bekerja lebih giat. Agar pegawai bekerja lebih giat maka mereka perlu diberi motivasi dengan berbagai cara. Pada umumnya tingkah laku manusia dilakukan secara sadar, artinya selalu didorong oleh keinginan untuk mencapai tujuan tertentu. Sedangkan menurut Gómez-Mejía, (Meija, Gomez, Luis R David B, 2012) Motivation that which energizes, directs, and sustains human behavior. In HRM, a person's desire to do the best possible job or to exert the maximum effort to perform assigned tasks. Artinya motivasi itu yang memberikan energi, mengarahkan, dan memelihara perilaku manusia. Dalam manajemen sumber daya manusia, keinginan seseorang untuk melakukan yang terbaik mungkin pekerjaan atau untuk mengerahkan upaya maksimal untuk melakukan tugas yang diberikan.

Menurut Kalimullah dalam Manzoor (Manzoor, 2011) Motivation is a set of courses concerned with a kid of strength that boosts performance and directs towards accomplishing some definite targets. Artinya motivasi adalah seperangkat program yang bersangkutan dengan kekuatan guna meningkatkan kinerja dan mengarahkan kepada pencapaian beberapa target yang pasti. Motivasi kerja adalah sikap seseorang terhadap pekerjaannya yang mengarah pada kepuasan kerja Herzberg dalam Robbins, (Herzberg, 2009) Motivasi kerja diartikan sebagai keadaan dalam diri individu yang mendorong keinginan individu untuk melakukan kegiatankegiatan tertentu guna mencapai tujuan. Menurut Ridwan Purnama dalam jurnalnya yang berjudul Pengaruh Motivasi Kerja terhadap Produktivitas Kerja Karyawan pada Bagian Produlsi CV. Epsilon Bandung, (Purnama, 2008) Motivasi kerja adalah keseluruhan proses pemberian motivasi bekerja kepada bawahan sedemikian rupa sehingga mereka mau bekerja dengan ikhlas demi tercapainya tujuan organisasi dengan efisien dan ekonomis. Dengan adanya pemberian motivasi kerja kepada karyawan memungkinkan perusahaan tersebut dapat mencapai produktivitas yang diharapkan karena para anggotanya termotivasi untuk lebih giat bekerja, berkarya, mencurahkan segenap kemampuannya, pengetahuan dan keterampilan yang mereka miliki.

Motivasi ini merupakan subjek penting, karena manajer perlu memahami orang-orang berperilaku tertentu agar dapat mempengaruhinya untuk bekerja sesuai dengan yang diinginkan organisasi. Faktor-faktor yang mempengaruhi motivasi menurut Suwatno (1996:236) dalam jurnal Syamsul Hadi Senen dan Siti Solihat yang berjudul Pengaruh Motivasi Kerja dan Kemampuan Kerja Karyawan terhadap Produktivitas Kerja Karyawan pada PT.Safilindo Permata (Senen, Hadi Syamsul dan Solihat, 2008) adalah prestasi kerja, pengharapan, sifat dan ruang lingkup, peningkatan, tantangan, tanggung jawab, administrasi dan manajemen, supervisi, hubungan ntar perseorangan, kondisi kerja, gaji, status, dan keamanan kerja.

Dimensi motivasi menurut David McClelland, seorang ahli psikologi bangsa Amerika dari Universitas Harvard, dalam teori motivasinya "Achievment Theory" mengemukakan bahwa produktivitas seseorang sangat ditentukan oleh "virus mental" yang ada pada dirinya. Virus mental adalah kondisi jiwa yang mendorong seseorang untuk mampu mencapai prestasinya secara maksimal. Virus mental yang di maksud terdiri dari 3 dorongan kebutuhan menurut David M)cClelland dalam James L Gibson (Gibson, James L, John M, Ivancevich, James H, Donnelly Jr, 2012) yaitu:

1. Need for Achievment (Kebutuhan dalam mencapai kesuksesan) yaitu kemampuan untuk mencapai hubungan kepada standar perusahaan yang telah ditentukan juga perjuangan karyawan untuk menuju keberhasilan.

2. Need for Power (kebutuhan dalam kekuasaan atau otoritas kerja) yaitu kebutuhan untuk membuat orang berprilaku dalam keadaan yang wajar dan bijaksana didalam tugasnya masing-masing. 
3. Need for Affiliation (kebutuhan untuk berafiliasi) yaitu hasrat untuk bersahabat dan mengenal lebih dekat rekan kerja atau para karyawan di dalam organisasi.

Kinerja karyawan merupakan suatu hal yang sangat penting dalam upaya perusahaan untuk mencapai tujuannya serta menjadi salah satu faktor utama keberhasilan suatu perusahaan. Pada dasarnya kinerja seorang karyawan merupakan hal yang bersifat individual karena setiap karyawan mempunyai tingkat kemampuan yang berbeda-beda dalam mengerjakan pekerjaannya. Segala upaya manajemen di dalam perusahaan, khususnya Manajemen Sumber Daya Manusia (MSDM) adalah untuk mempertinggi, baik kinerja individu maupun organisasional. Veithzal Rivai dan Ella Jauvani (Rivai, Veithzal dan Sagala, 2010) mengemukakan bahwa Kinerja merupakan perilaku nyata yang ditampilkan setiap orang sebagai prestasi kerja yang dihasilkan oleh karyawan sesuai dengan perannya dalam perusahaan." Menurut Robbins dan Coulter (Robbins, Stephen P, 2012), kinerja adalah hasil akhir dari sebuah aktifitas.

Sedangkan Hasibuan (Hasibuan, 2013) menyatakan bahwa prestasi kerja adalah suatu hasil kerja yang dicapai seseorang dalam melaksanakan tugas-tugas yang dibebankan kepadanya yang didasarkan kecakapan, pengalaman, kesungguhan, serta waktu. Charity Tino Firei dalam International Journal yang berjudul The Unique Factors Affecting Employee Performance In Non Profit Organisations (Tinoferei, 2011) "Performance is the accomplishment of a given task measured against pre-set standards of acuracy, completeness, cost and speed." Kinerja adalah prestasi yang diberikan atas ukuran tugas terhadap ukuran ketepatan, kelengkapan, ongkos dan kecepatan.

Berdasarkan definisi kinerja karyawan dari para ahli diatas, dapat disimpulkan bahwa kinerja merupakan kualitas dan kuantitas dari suatu hasil kerja (output) individu maupun kelompok dalam suatu aktivitas tertentu yang diakibatkan oleh kemampuan alami atau kemampuan yang diperoleh dari proses belajar serta keinginan untuk berprestasi. Kegiatan penilaian kinerja sendiri dimaksudkan untuk mengukur kinerja masing-masing tenaga kerja dalam mengembangkan dan meningkatkan kualitas kerja, sehingga dapat diambil tindakan yang efektif semisal pembinaan berkelanjutan maupun tindakan koreksi atau perbaikan atas pekerjaan yang dirasa kurang sesuai dengan deskripsi pekerjaan. Satu upaya untuk memperoleh hasil terbaik dari organisasi, kelompok dan individu-individu melalui pemahaman dan penjelasan kinerja dalam suatu kerangka kerja atas tujuan-tujuan terencana, standar dan persyaratan-persyaratan atribut atau kompetensi yang disetujui bersama

Suatu organisasi dibentuk untuk mencapai tujuan organisasi. Pencapaian tujuan organisasi menunjukkan hasil kerja/prestasi organsisasi dan menunjukkan kinerja organisasi. Hasil kerja organisasi diperoleh dari serangkaian aktivitas yang dijalankan. Aktivitas tersebut dapat berupa pengelolaan sumberdaya organisasi maupun proses pelaksanaan kerja yang diperlukan untuk mencapai tujuan organisasi. Seorang karyawan tentunya menginginkan adanya umpan balik mengenai prestasi kerja mereka sebagai suatu tuntutan untuk perilaku di kemudian hari, tuntutan itu terutama diinginkan oleh para karyawan baru yang sedang berusaha memahami tugas dan melaksanakan tugas kewajiban yang mereka laksanakan .Instrumen penilaian kinerja dapat digunakan untuk mereview kinerja, peringkat kerja, penilaian kinerja, penilaian kerja dan sekaligus evaluasi karyawan sehingga dapat diketahui mana karyawan yang mampu melaksanakan pekerjaan secara baik, efisien, efektif, dan produktif sesuai dengan tujuan perusahaan.

George dan Jones (George and Jones, 2002) mengemukakan bahwa: "penilaian kinerja merupakan evaluasi kinerja untuk mendorong motivasi karyawan, kinerja dan memberikan informasi yang akan digunakan dalam pengambilan keputusan manajerial." Menurut R. Wayne Mondy (R. Wayne Mondy, 2008) penilaian kinerja (performance appraisal) adalah sistem formal untuk menilai dan mengevaluasi kinerja tugas tim atau individu" proses penilaian kinerja menurut $\mathrm{R}$ Wayne Mondy (R. Wayne Mondy, 2008) Kinerja yang baik akan terbentuk melalui keterkaitan antara satu dengan yang lainnya. Adanya hubungan yang baik antara semua lapisan di perusahaan tersebut akan mempermudah karyawan untuk menjalankan tugasnya dengan baik. Menurut Anwar Prabu dalam jurnal Hari Mulyadi dan Nina Marliana yang berjudul Pengaruh Motivasi dan Disiplin Kerja Karyawan Terhadap Kinerja Karyawan pada Departemen Weaving PT. Adetex Cabang Banjaran Kab. Bandung (Mulyadi, Hari dan Marliana, 2010) Kinerja karyawan adalah prestasi kerja atau hasil kerja (output) baik kualitas maupun kuantitas yang dicapai SDM persatuan periode waktu dalam melaksanakan tugas kerjanya sesuai dengan tanggung jawab yang diberikan kepadanya.

Dalam suatu perusahaan kinerja merupakan hasil kerja atas suatu pekerjaan yang telah dihasilkan dari perilaku nyata karyawan secara kualitas dan kuantitas sesuai dengan 
tugas yang diberikan kepadanya. Kinerja yang baik akan terbentuk melalui keterkaitan antara satu dengan yang lainnya. Hubungan yang baik antara semua lapisan di perusahaan tersebut akan mempermudah karyawan. Dimensi yang di kemukakan oleh Gomez-Mejia, Balkin, dan Cardy (Meija, Gomez, Luis R David B, 2012) mengemukakan bahwa dimensi kinerja terdiri dari:

1. Quality of work (Kualitas pekerjaan)

2. Quantity of work performed (Kuantitas pekerjaan yang dilakukan)

3. Interpersonal effectiveness (Efektivitas interpersonal)

4. Competencies (Kompetensi)

\section{METODE}

Penelitian ini menggunakan pendekatan manajemen sumber daya manusia khususnya mengenai pengaruh kompensasi dan motivasi kerja terhadap kinerja karyawan di Rumah Sakit Umum Daerah Subang. Oleh karena itu yang menjadi variabel independent atau variabel bebas adalah kompensasi dengan indikatornya mencakup gaji, upah, insentif, dan kompensasi tidak langsung, serta motivasi kerja yang terdiri dari tiga dimensi yaitu need of achievment (kebutuhan atas penghargaan), need of power (kebutuhan akan kekuasaan), dan need of affiliation (kebutuhan aka berafiliasi). Sedangkan masalah penelitian yang merupakan dependent variabel atau variabel terikat adalah kinerja pegawai dengan indikatornya yang terdiri dari Quality of work (kualitas kerja), Quantity of work performed (kuantitas hasil kinerja), Interpersonal effectiveness (efektifitas interpersonal), dan Competencies (kompetensi). Metode yang digunakan dalam penelitian ini adalah metode penelitian deskriptif dan verifikatif. Menurut Arikunto (2002:9) dalam Jurnal Eded Tarmedi dan Penti Nurarsi yang berjudul Pengaruh Preceived Quality dari Brand Equity Terhadap Keputusan Pembelian Deterjen Bukrim (Tarmedi \& Asri, 2009) Penelitian deskriptif adalah penelitian yang bertujuan untuk memperoleh deskripsi tentang ciri-ciri variabel, Arikunto (2002:7) mengemukakan mengenai sifat penelitian verifikatif pada dasarnya ingin menguji kebenaran dari suatu hipotesis penelitian yang dilaksanakan melalui pengumpulan data di lapangan.

Pada penelitian ini yang menjadi objek penelitian adalah perawat rumah sakit umum Subang. Penelitian ini dilakukan pada kurung waktu kurang dari satu maka metode penelitian yang digunakan adalah cross sectional method. Sebagaimana yang dikemukakan oleh Husein Umar (Umar, 2008) pendekatan cross sectional yaitu metode penelitian dengan cara mempelajari objek dalam kurun waktu tertentu (tidak berkesinambungan dalam jangka waktu panjang) dalam penelitian yang menggunakan metode ini, informasi dari sebagai populasi dikumpulkan langsung di tempat kejadian secara empirik dengan tujuan untuk mengetahui pendapat dari sebagian populasi terhadap objek yang sedang diteliti di lapangan. Menurut Suharsimi Arikunto (2003:108) dalam Jurnal Sunanta Syarif dan Faisal Mundir yang berjudul Pengaruh Diferensasi Produk Terhadap Kepuasan Pembelian Flashdisk Kingston (Syarif, Sunanta dan Mundir, 2008) yang dimaksud dengan populasi adalah keseluruhan subjek penelitian. Populasi dalam penelitian ini adalah keperawatan kontrak Rumah Sakit Umum Subang sebanyak 112 orang.

Data primer diperoleh peneliti dengan menggunakan teknik pengumpulan data berupa observasi, wawancara maupun menyebaran kuesioner kepada sumber data. Maholtra (Maholtra, 2009) mengungkapkan definisidefinisi data primer dan sekunder, jenis data dan sumber data yang digunakan dalam penelitian ini, penulis mengumpulkan dan menyajikannya dalam bentuk tabel di dapat dari hasil wawancara dan data bagian HRD rumah sakit umum subang.

Teknik pengumpulan data pada cara yang digunakan untuk mengumpulkan data yang diperlukan. Sumber data yang diperoleh dalam penelitian ini di dapat dengan menggunakan beberapa teknik penelitian sebagai berikut:

1. Studi kepustakaan yaitu dilakukan untuk memperoleh data sekunder yang akan digunakan menjadi landasan teori masalah yang diteliti. Dalam kepustakaan ini penulis membaca dan mempelajari buku-buku, literatur, website, dan materi yang berhubungan dengan masalah yang diteliti. Hal tersebut ditunjukan untuk memperoleh informasi serta gambaran yang jelas mengenai masalah yang diteliti.

2. Kuesioner merupakan teknik pengumpulan data yang dilakukan dengan cara memberi seperangkat pertanyaan atau pernyataan tertulis kepada responden untuk dijawabnya (Sugiyono, 2013). Kuesioner yang penulis sebarkan berisi pertanyaan yang dapat dijadikan sebagai pengukuran dari indikatorindikator baik variabel kompensasi, motivasi kerja maupun variabel Y (kinerja karyawan) yang ditujukan untuk perawat kontrak rumah sakit umum Subang. Langkahlangkah yang ditempuh dalam penyusunan angket antara lain:

a) Menyusun kisi-kisi angket atau daftar pertanyaan

b) Merumuskan item-item pertanyaan dan alternatif jawaban. Jenis instrumen 
yang digunakan dalam angket merupakan instrumen yang bersifat tertutup, yaitu seperangkat alat tulis dan disertai dengan alternatif jawaban yang disediakan, sehingga responden hanya memilih jawaban yang tersedia.

c) Menetapkan pemberian skor untuk setiap item pertanyaan. Pada penelitian ini setiap pendapat responden atas pertanyaan diberi nilai dengan skala Interval.

3. Observasi, yaitu pengamatan dan peninjauan langsung terhadap objek yang sedang diteliti khususnya mengenai kompensasi, motivasi kerja serta kinerja perawat kontrak rumah sakit umum daerah Subang.

4. Wawancara, yaitu pengumpulan data atau informasi melalui komunikasi langsung kepada pihak-pihak yang berkepentingan, dalam hal ini adalah perawat kontrak rumah sakit umum Subang.

5. Studi Literatur, yaitu kegiatan pengumpulan informasi terkait teori maupun uraian yang berhubungan dengan masalah serta variabel yang diteliti yang terdiri dari kompensasi, motivasi kerja dan kinerja karyawan. Adapun dalam pelaksanaannya studi literatur ini didapatkan dari berbagai sumber seperti a) perpustakaan dibeberapa universitas yaitu UPI, Unpar, Widyatama, dan SBM ITB, b) skripsi, c) jurnal, d) media cetak (majalah) dan e) internet.

\section{TEMUAN DAN PEMBAHASAN}

Hasil dari skor pengumpulan data variabel kompensasi adalah sebesar 8102, dengan demikian presentase dimensi kompensasi menurut tanggapan 112 responden adalah (8102:16464x100\%) 49,21\% menyatakan bahwa variabel kompensasi masih belum sesuai dengan apa yang diharapkan. Aspek kompensasi berdasarkan persepsi karyawan memperoleh skor 8102, apabila di persentasekan ke dalam skor ideal maka diperoleh persentase sebesar 49,21\%, yang artinya menurut Moch Ali (Ali, 1985) termasuk ke dalam kategori "hampir setengahnya" responden menyatakan bahwa kompensasi karyawan di Rumah Sakit Umum Daerah Subang dalam kategori cukup rendah.

Hasil dari skor pengumpulan data variabel motivasi adalah sebesar 5066, dengan demikian presentase dimensi motivasi menurut tanggapan 112 responden adalah (5066:9408x100\%) 53,84\% menyatakan bahwa dimensi motivasi masih belum sesuai dengan apa yang diharapkan. Berdasarkan Tabel 4.8 aspek motivasi berdasarkan persepsi karyawan memperoleh skor 5066, apabila di persentasekan ke dalam skor ideal maka diperoleh persentase sebesar $53,84 \%$, yang artinya menurut Moch Ali (Ali, 1985) termasuk ke dalam kategori "sebagian besar" responden menyatakan bahwa variabel motivasi karyawan di Rumah Sakit Umum Subang dalam kategori sedang. Hasil dari pengolahan data penelitian melalui kuesioner yang disebar kepada karyawan di Rumah Sakit Umum Subang diperoleh skor ideal motivasi adalah 9408 untuk 12 item pertanyaan. Perolehan skor berdasarkan hasil pengolahan data pada variabel motivasi adalah 5066.

Aspek kinerja berdasarkan persepsi karyawan memperoleh skor 5463, apabila di persentasekan ke dalam skor ideal maka diperoleh persentase sebesar $53,60 \%$, yang artinya menurut Moh Ali (Ali, 1985) termasuk ke dalam kategori "sebagian besar" responden menyatakan bahwa kinerja karyawan di Rumah Sakit Umum Subang dalam kategori sedang. Hasil dari pengolahan data penelitian melalui kuesioner yang disebar kepada karyawan di Rumah Sakit Umum Subang diperoleh skor ideal kinerja adalah 10192 untuk 13 item pertanyaan. Perolehan skor berdasarkan hasil pengolahan data pada variabel kinerja adalah 5463.

Dengan menggunakan program SPSS 16.0 for Windows, diperoleh hasil koefisien regresi sebagai berikut:

TABEL 1

KORELASI ANTAR VARIABEL

\begin{tabular}{ccccc}
\hline & & & & \\
& & Kinerja & Kompensasi & Motivasi \\
Pearson & Kinerja & 1,000 &, 377 &, 475 \\
Correaltion & $\begin{array}{c}\text { Kompensasi } \\
\text { Motivasi }\end{array}$ &, 377 & 1,000 &, 446 \\
&, 475 &, 446 & 1,000 \\
\hline \multirow{2}{*}{$\begin{array}{c}\text { Sig. (1- } \\
\text { tailed) }\end{array}$} & Kompensasi &, 000 &, 000 &, 000 \\
& Motivasi &, 000 &, 000 & - \\
\hline \multirow{5}{*}{$\mathrm{N}$} & Kinerja & 112 & 112 & 112 \\
& Kompensasi & 112 & 112 & 112 \\
& Motivasi & 112 & 112 & 112 \\
\hline
\end{tabular}

Sumber : Hasil pengolahan 2016

Berdasarkan tabel di atas dapat digambarkan, bahwa Nilai yang diperoleh pada Tabel 1 yaitu korelasi antara kompensasi terhadap kinerja karyawan adalah sebesar 0,377 artinya terdapat hubungan yang rendah antara kompensasi terhadap kinerja karyawan sedangkan korelasi antara motivasi terhadap kinerja karyawan adalah sebesar 0,446 artinya terdapat hubungan yang sedang antara motivasi terhadap kinerja karyawan, berdasarkan interpretasi koefisien korelasi nilai $\mathrm{r}(0,80-1,000)$. Nilai $p$-value pada kolom sig. (1-tailed) $0,000<0,05$ level of significant $(\alpha)$ berarti $\mathrm{Ha}>0$. Artinya 
kompensasi dan motivasi berkorelasi dengan kinerja karyawan.

Untuk mengetahui besarnya pengaruh variabel kompensasi terhadap variabel kinerja karyawan, hasil perhitungan koefisien determinasi untuk kompensasi dan motivasi kerja terhadap kinerja karyawan adalah 55\%. Dengan kata lain kinerja karyawan dipengaruhi $55 \%$ oleh kompensasi dan motivasi kerja, sedangkan $45 \%$ dipengaruhi oleh faktor lainnya. Nilai tersebut dapat dilihat pula pada output koefisien korelasi pada lambang $r$ square. Hasil perhitungan koefisien korelasi tersebut menunjukkan bahwa besarnya KD (koefisien determinasi) untuk kompensasi terhadap kinerja karyawan adalah $14 \%$ artinya kinerja karyawan dipengaruhi oleh kompensasi $14 \%$ dan sisanya $86 \%$ dipengaruhi oleh faktor lainnya. Dan koefisien determinasi untuk motivasi kerja terhadap kinerja karyawan adalah $23 \%$ yang berarti perubahan pada variabel sebesar $23 \%$ dipengaruhi oleh motivasi kerja sedangkan $77 \%$ sisanya dipengaruhi oleh faktor lain. Secara statistik, hipotesis yang akan diuji dalam rangka pengambilan keputusan penerimaan atau penolakan hipotesis dapat dirumuskan sebagai berikut

Hipotesis Simultan

Ho : $\leq 0$, artinya tidak terdapat pengaruh positif dari kompensasi dan motivasi kerja terhadap kinerja karyawan

$\mathrm{Ha}:>0$, artinya terdapat pengaruh positif dari kompensasi dan motivasi kerja terhadap kinerja karyawann.

TABEL 2

NILAI SIGNIFIKASI UJI F

\begin{tabular}{lllllll}
\hline \multicolumn{1}{c}{ ANOVA $^{\mathbf{b}}$} & \multicolumn{1}{c}{ Model } & $\begin{array}{c}\text { Sum of } \\
\text { Squares }\end{array}$ & Df & $\begin{array}{r}\text { Mean } \\
\text { Square }\end{array}$ & F & Sig. \\
\hline 1 & Regression & 648.673 & 2 & 324.337 & 2.444 & $.042^{\mathrm{a}}$ \\
& Residual & 14462.746 & 109 & 132.686 & & \\
$\quad$ Total & 15111.420 & 111 & & & \\
a. Predictors: (Constant), Motivasi, Kompensasi & & \\
b. Dependent Variable: kinerja
\end{tabular}

Sumber: pengolahan data 2016

Berdasarkan Tabel 2 di atas, diperoleh nilai signifikansi sebesar 0.042. karena nilai significance $F$ Change lebih kecil dari $\alpha(5 \%)$ yaitu $0.042<0.05$, maka $\mathrm{H}_{\mathrm{o}}$ ditolak, berarti kompensasi dan motivasi secara simultan berpengaruh terhadap kinerja pegawai.

Pengujian hipotesis secara parsial dilakukan untuk mengetahui pengaruh variabel independen terhadap variabel dependen secara sendiri-sendiri, untuk itu hipotesis dalam penelitian ini adalah:
TABEL 3 NILAI SIGNIFIKASI UJI T

\begin{tabular}{|c|c|c|c|c|c|}
\hline \multirow[b]{3}{*}{ Model } & ficients ${ }^{\mathrm{a}}$ & & & \multirow[b]{3}{*}{$\mathrm{T}$} & \multirow[b]{3}{*}{ Sig. } \\
\hline & \multicolumn{2}{|c|}{$\begin{array}{l}\text { Unstandardized } \\
\text { Coefficients }\end{array}$} & $\begin{array}{l}\text { Standardized } \\
\text { Coefficients }\end{array}$ & & \\
\hline & B & $\begin{array}{l}\text { Std. } \\
\text { Error }\end{array}$ & Beta & & \\
\hline 1 (Constant) & 56.581 & 6.535 & & 8.659 & .000 \\
\hline Kompensasi & .047 & .069 & .265 & .681 & .0498 \\
\hline Motivasi & .248 & .113 & .409 & 2.193 & .030 \\
\hline $\begin{array}{l}\text { a. Dependent } \\
\text { kinerja }\end{array}$ & Variab & & & & \\
\hline
\end{tabular}

Sumber: Hasil pengolahan data, 2016.

Berdasarkan Tabel 3dapat dilihat hasil Uji T. Apabila nilai $t_{\text {hitung }} \leq(\alpha=0,05)$ maka dapat dikatakan bahwa variabel bebas dari $t_{\text {hitung }}$ tersebut berpengaruh signifikan terhadap variabel terikatnya, sedangkan apabila nilai $\mathrm{t}_{\text {hitung }} \geq(\alpha=$ $0,05)$ maka dapat dikatakan bahwa variabel bebas tidak berpengaruh signifikan terhadap variabel terikatnya. Nilai $t_{\text {hitung }}$ dari variabel kompensasi sebesar $0,0498 \leq 0,05$ sehingga variabel kompensasi berpengaruh signifikan terhadap variabel kinerja karyawan pada $(\alpha=0,05)$ sama halnya dengan pengaruh variabel motivasi kerja terhadap variabel kinerja karyawan yang lebih kecil dari $0,05(0,030 \leq 0,05)$ sehingga dapat dikatakan bahwa variabel motivasi kerja berpengaruh signifikasi tehadap variabel kinerja karyawan dengan kata lain kompensasi dan motivasi kerja terhadap kinerja karyawan berpengaruh signifikan terhadap kinerja karyawan dengan taraf keyakinan $95 \%$.

Penelitian ini mencoba melakukan pembuktian dan pembahasan mengenai kompensasi, motivasi dan kinerja karyawan di Rumah Sakit Umum Subang. Selanjutnya menerangkan variabel kompensasi dan motivasi berpengaruh terhadap kinerja karyawan di Rumah Sakit Umum Subang. Hasil penelitian ini memberikan gambaran bahwa kinerja karyawan dipengaruhi oleh kompensasi dan motivasi, dari hasil penelitian ini diharapkan akan menyumbangkan data untuk melakukan perbaikan selanjutnya khususnya pada Rumah Sakit Umum Subang. Lebih jauhnya untuk peneliti berikutnya terbukti bahwa kinerja pegawai dipengaruhi oleh kompensasi dan motivasi.

Total pengaruh secara keseluruhan adalah $39,4 \%$, efek faktor lain yang tidak diteliti terhadap kinerja pegawai ditunjukkan oleh nilai $\rho y \varepsilon=0,606$ sebesar $60,6 \%$ merupakan faktor lain yang tidak diteliti dalam penelitian ini yang mempengaruhi kinerja karyawan. Hasil penelitian ini menguatkan bahwa jika variabel kompensasi dan motivasi secara bersama-sama dilakukan dengan baik, maka akan berpengaruh terhadap peningkatan kinerja karyawan. Jika faktor-faktor 
lain yang mempengaruhi kinerja pegawai ditambah kemungkinan kontribusinya akan lebih sempurna. Sejalan dengan pendapat Susilo Martoyo (Martoyo, 2007): "Sebetulnya memang banyak faktor yang dapat mempengaruhi kinerja karyawan, antara lain: motivasi, kepuasan kerja, tingkat stres, kondisi fisik pekerjaan, rekrutmen, analisis jabatan, deskripsi jabatan, sistem kompensasi, aspek-aspek ekonomis, aspek-aspek teknis, perilaku-perilaku lainnya."

Berdasarkan hasil kajian serta penelitian mengenai pengaruh kompensasi dan motivasi terhadap kinerja karyawan Rumah Sakit Umum Subang, maka dihasilkan temuan-temuan empiris sebagai berikut:

1. Berdasarkan hasil penelitian yang bersifat empirik mengenai pelaksanaan kompensasi karyawan Rumah Sakit Umum Subang, dihasilkan temuan bahwa Gaji yang diberikan sangat sesuai dengan masa jabatan yang mereka tempati dan terpenuhinya asuransi kesehatan telah memberikan kontribusi yang rendah bagi karyawan dalam mencapai kinerja.

2. Berdasarkan hasil penelitian yang bersifat empirik mengenai pelaksanaan motivasi karyawan Rumah Sakit Umum Subang bahwa motivasi setiap orang mampu menjadi pemimpin telah memberikan kontribusi yang sedang bagi karyawan dalam mencapai kinerja.

3. Berdasarkan hasil penelitian yang bersifat empirik mengenai pelaksanaan kinerja karyawan. Rumah Sakit Umum Subang, dihasilkan temuan bahwa mereka selalu berdiskusi untuk menyelesaikan suatu pekerjaan memberikan kontribusi yang sedang bagi karyawan dalam mencapai kinerja.

4. Berdasarkan hasil penelitian secara empirik diperoleh keterangan bahwa pelaksanaan kompensasi dan motivasi yang diterapkan di Rumah Sakit Umum Subang mempunyai pengaruh secara keseluruhan sebesar 55\% terhadap kinerja, sedangkan $45 \%$ dipengaruhi faktor-faktor lainnya.

\section{KESIMPULAN DAN REKOMENDASI}

Berdasarkan pembahasan teori, hasil penelitian, dan pengujian analisis regresi yang dilaksanakan mengenai pengaruh kompensasi dan motivasi terhadap kinerja karyawan di Rumah Sakit Umum Subang pegawai dapat disimpulkan sebagai berikut:

1. Gambaran mengenai kompensasi karyawan di Rumah Sakit Umum Subang dapat dilihat dari dimensi-dimensinya yang terdiri dari gaji, insentif upah dan kompensasi tidak langsung. Diperoleh skor ideal 16464 dengan persentase 49,21\% dalam kategori hampir setengahnya responden mengemukakan bahwa kompensasi pada karyawan di Rumah Sakit Subang berada pada kategori cukup. Skor tertinggi terdapat pada item pertanyaan Gaji yang diberikan sangat sesuai dengan masa jabatan yang saya tempati dan terpenuhinya asuransi kesehatan. Skor terendah terdapat pada item pertanyaan Insentif yang diterima sangat sesuai dengan hasil kerja yang dilakukan dan Kompensasi yang diberikan sangat tinggi. Ini membuktikan bahwa sistem insentif masih belum cukup sesuai dengan apa yang diharapkan karyawan.

2. Gambaran mengenai motivasi pada karyawan di Rumah Sakit Umum Subang dapat dilihat dari dimensi-dimensinya yang terdiri dari Need of achievment dan Need of power diperoleh skor ideal 9408 dengan persentaase $53,84 \%$ dalam kategori sebagian besar responden mengemukakan bahwa kompensasi pada karyawan di Rumah Sakit Umum Subang berada pada kategori cukup. skor tertinggi terdapat pada item pertanyaan Saya mampu menjadi pemimpin. Skor terendah terdapat pada item Saya selalu terlibat dalam kegiatan organisasi dalam pekerjaan. Ini membuktikan pihak manajemen masih belum bisa memberikan kepercayaan lebih kepada karyawan.

3. Gambaran mengenai kinerja pada karyawan di Rumah Sakit Umum Subang dapat dilihat dari dimensi-dimensinya yang terdiri dari quality of work, quantity of work, Interpersonal Effectiveness, dan competencies diperoleh skor ideal 10192 dengan persentase $53,60 \%$ dalam kategori sebagian besar responden mengemukakan bahwa kompensasi pada karyawan di Rumah Sakit Umum Subang berada pada kategori cukup. skor tertinggi terdapat pada item pertanyaan Saya dan rekan kerja selalu berdiskusi dalam menyelesaikan masalah pekerjaan. Skor terendah terdapat pada item pertanyaan Hasil kerja saya selalu melebihi target yang telah ditentukan. Masih banyak karyawan yang belum bisa mencapai target kinerja yang direncanakan oleh pihak Rumah Sakit.

4. Kompensasi dan Motivasi memiliki pengaruh yang positif terhadap kinerja karyawan Rumah Sakit Umum Subang dengan tingkat korelasi yang kuat. Hal ini menunjukkan bahwa semakin tinggi kompensasi dan semakin tinggi motivasi, maka akan semakin tinggi pula kinerja karyawan tersebut. 
5. Kompensasi mempunyai pengaruh positif terhadap kinerja karyawan dengan tingkat korelasi yang sangat kuat. Hal ini menunjukan bahwa semakin tinggi kompensasi maka semakin tinggi pula kinerja karyawan tersebut.

6. Motivasi kerja mempunyai pengaruh positif terhadap kinerja karyawan dengan tingkat korelasi sangat kuat. Hal ini menunjukkan bahwa semakin tinggi motivasi kerja, maka akan semakin tinggi pula kinerja karyawan tersebut.

Berdasarkan hasil penelitian, maka penulis merekomendasikan beberapa hal mengenai pengaruh kompensasi dan motivasi terhadap kinerja karyawan di Rumah Sakit Subang:

1. Berdasarkan tanggapan responden karyawan mengenai variabel kompensasi terdapat indikator insentif yang diterima sangat sesuai dengan hasil kerja yang dilakukan memperoleh penilaian terkecil dari responden di Rumah Sakit Umum Daerah Kelas B Kabupaten Subang. Artinya sistem insentif yang diterima belum sesuai dengan hasil kerja mereka hal ini membuktikan bahwa karyawan ingin perubahan dalam sistem insentifnya. Insentif yang baik sesuai dengan hasil kerja mereka tanpa pilih kasih akan membuat kerja mereka lebih dihargai.

2. Berdasarkan tanggapan responden karyawan mengenai variabel motivasi terdapat indikator Saya selalu terlibat dalam kegiatan organisasi dalam pekerjaan memperoleh penilaian paling rendah. Pimpinan Rumah Sakit Umum Subang mempunyai peranan penting untuk memotivasi pegawainya agar terciptanya suana kerja yang baik. Para pegawai yang satu dengan pegawai yang lain bisa saling membantu dan saling berhubungan sehingga tujuan organisasi bisa tercapai dengan baik. Pimpinan harus bisa memberikan teladan yang baik bagi para pegawainya.

3. Berdasarkan taggapan responeden karyawan mengenai variabel kinerja, pada indikator Hasil kerja saya selalu melebihi target yang telah ditentukan memiliki penilaian terendah. Artinya hasil kerja mereka tidak sesuai dengan target. Disini diperlukan peran pimpinan dengan memberikan motivasi-motivasi kepada mereka atau dengan sikap pimpinan yang memberikan contoh yang bisa memacu semngat kerja mereka. Ini membuktikan bahwa kinerja pegawai memang dipengaruhi oleh kompensasi dan motivasi.

Hasil penelitian menyatakan bahwa kompensasi dan motivasi berpengaruh positif terhadap kinerja karyawan, maka penulis merekomendasikan agar pihak Rumah Sakit Umum Subang mempertahankan apa yang sudah bagus dan meningkatkan apa yang masih kurang sehingga akan terwujud tujuan organisasi bersama.

\section{REFERENCES}

Ali, M. (1985). Penelitian Kependidikan Prosedur dan Strategi. Bandung: Angkasa.

Alma, B. (2004). Kewirausahaan. Bandung: Alfabeta.

Dessler, G. (2011). Human Resource Management. New Jersey: Pearson Education.

Effendi Marihot Tua. (2010). Manajemen Sumber Daya Manusia: Pengadaan, Pengembangan, Pengkomprehensipan dan Peningkatan Produktivitas Pegawai. Jakarta: PT. Gramedia Widiasarana Indonesia.

George and Jones. (2002). Organizational Behavior (Third Edit). New Jersey: Pearson Education.

Gibson, James L, John M, Ivancevich, James H, Donnelly Jr, R. K. (2012). Organizations: Behavior, Structure, Processes. Fourteenth.

Hasibuan, Malayu, S. . (2003). Manajemen Sumber Daya Manusia. Jakarta: Bumi Aksara.

Hasibuan, M. S. . (2013). Manajemen Sumber Daya Manusia (edisis rev). Jakarta: pt.bumi aksara.

Herzberg, F. (2009). The Motivation to Work. New York: Library Of Congress Cataloging In-Publication Data.

Kementrian Kesehatan. (2014). Laporan Akuntabilitas Kinerja Kementrian Kesehatan Tahun 2014. http://doi.org/www.depkes.go.id

Maholtra, N. K. (2009). Marketing Research and Applied Orientation. New Jersey: Pearson Education.

Manzoor, Q.-A. (2011). Impact of Employees Motivation on Organizational Effectiveness. Business Management and Strategy, 3(1), 1-12. http://doi.org/10.5296/bms.v3i1.904

Martoyo, S. (2007). Manajemen Sumber Daya Manusia (Edisi 5). Yogyakarta: BPFE Yogyakarta.

Meija, Gomez, Luis R David B, B. and R. L. C. (2012). Managing Human Resources. United States: Pearson Education, Inc,. Publishing As Prentice Hall.

Mulyadi, Hari dan Marliana, N. (2010). Pengaruh Motivasi dan disiplin Kerja Karyawan Terhadap Kinerja Karyawan Pada Departemen Weaving PT. Adetex Cabang 
Banjaran Kab. Bandung, Volume 9,N, 4075.

Pamela F. (2012). Performance Management and Compensation as Drivers of Organization Competitiveness : The Philippine Perspective $\mathrm{PhD}$ Student, College of Business, 3(21), 20-30.

Purnama, R. (2008). Pengaruh Motivasi Kerja Terhadap Produktivitas Kerja Karyawan Pada Bagian Produlsi CV . Epsilon Bandung, Volume 7, 58-72.

R. Wayne Mondy. (2008). Penilaian Kinerja. Retrieved June 22, 2016, from https://mgtofsdm.wordpress.com/2014/08/2 1/kinerja/

Rivai, Veithzal dan Sagala, E. J. (2010). Manajemen Sumber Daya Manusia Untuk Perusahaan. Jakarta: Rajawali Pers.

Robbins, Stephen P, M. C. (2012). Management. New Jersey: Prentice Hall.

Senen, Hadi Syamsul dan Solihat, S. (2008). Pengaruh Motivasi Kerja Dan kemampuan
Kerja Karyawan Terhadap Produktivitas Kerja Karyawan Pada PT.Safilindo Permata, 7(September), 1-15.

Sugiyono. (2013). Metode Penelitian Bisnis. Bandung: Alfabeta.

Syarif, Sunanta dan Mundir, F. (2008). Pengaruh Deferensiasi Produk Terhadap Keputusan Pembelian Flashdisk Kingston, Volume 7, 44-57.

Tarmedi, E., \& Asri, P. N. (2009). Pengaruh Pereceived Quality Dari Brand Equity Terhadap Keputusan Pembelian Deterjen Bukrim, Volume 8, 35-49.

Tinoferei, C. (2011). The unique factors affecting employee performance in non-profit organisations. Pretoria: University of South Africa.

Umar, H. (2008). Strategic Management. Jakarta: PT Gramedia Pustaka Utama.

Yuniarsih, T. dan S. (2009). Manajemen Smber Daya Manusia Teori, aplikasi dan Isu Penelitian. Bandung: CV Alfabeta. 